
\title{
25 Research Soure \\ BA and TDZ in the Morphogenesis in Vitro of Passiflora Setacea
}

\section{Leticia da Silva Araújo ( $\nabla$ leticia_alcanfor@hotmail.com )}

Universidade Estadual do Norte Fluminense: Universidade Estadual do Norte Fluminense Darcy Ribeiro https://orcid.org/0000-0003-3623-1049

\section{Virginia Silva Carvalho}

Universidade Estadual do Norte Fluminense: Universidade Estadual do Norte Fluminense Darcy Ribeiro Andressa Leal Generoso

Universidade Estadual do Norte Fluminense: Universidade Estadual do Norte Fluminense Darcy Ribeiro Josefa Grasiela Silva Santana

Universidade Estadual do Norte Fluminense: Universidade Estadual do Norte Fluminense Darcy Ribeiro Glaziele Campbell

Universidade Estadual do Norte Fluminense: Universidade Estadual do Norte Fluminense Darcy Ribeiro Rafael Walter

Universidade Estadual do Norte Fluminense: Universidade Estadual do Norte Fluminense Darcy Ribeiro Maura da Cunha

Universidade Estadual do Norte Fluminense: Universidade Estadual do Norte Fluminense Darcy Ribeiro

\section{Research Article}

Keywords: 6- benzyladenine, thidiazuron, organogenesis, callogenesis, passion fruit

Posted Date: January 4th, 2022

DOl: https://doi.org/10.21203/rs.3.rs-747944/v1

License: (c) (1) This work is licensed under a Creative Commons Attribution 4.0 International License. Read Full License 


\section{Abstract}

Passiflora setacea DC (Passifloraceae) is considered an important species in the genetic breeding of passion fruit. However, its use is limited due to low seed germination. This paper aimed to study the effect of cytokinins 6-benzyladenine (BA) and thidiazuron (TDZ) on the in vitro morphogenesis of $P$. setacea using three explants: hypocotyl, nodal segment, and root segment. The explants were induced to morphogenesis in MS medium modified and with different concentrations of BA and TDZ. After 55 days, the percentage of calluses and shoots were evaluated, and anatomical characterization was performed. The three explants used in the in vitro morphogenesis of $P$. setacea showed callus and shoots formation, but in greater numbers in the nodal segments treated with BA. TDZ isolated affected equal to or less than BA on callus and shoots formation for the three explants. Direct and indirect organogenesis was observed in the three types of explants. From the results obtained for plant regeneration via in vitro morphogenesis of $P$. setacea, it is recommended to use a nodal segment in MSM medium and supplemented with $2.22 \mu \mathrm{mol} \mathrm{L}{ }^{-1}$ of BA.

\section{Key Message}

1. P. setacea has disease resistance genes, however, it has low germination via seminiferous and morphogenesis in vitro is a technique enabling the multiplication and regeneration of plants in vitro.

2. Different concentrations of cytokinins 6-benzyladenine and thidiazuron combined were used to promote the morphogenesis in vitro of $P$. setacea for three types of explants.

3. A protocol containing medium supplemented with $\mathrm{BA}$ is efficient for the morphogenesis in vitro of the nodal segment of $P$. setacea.

\section{Introduction}

Passiflora setacea DC. (Passifloraceae) is a wild species known populary as the passion fruit of sleeping, this species has resistance genes for to the main diseases that are common to sour passion fruit $(P$. edulis Sims), the most commercially used species (Fuhrmann et al., 2014; Viana et al., 2016; Sacoman et al., 2018). This characteristic encourages passion fruit in genetic breeding programs, aiming to obtain interspecific hybrids (Carvalho et al., 2019; Santos et al., 2019). However, it is reported a low percentage of germination via seeds and a low rooting capacity of cuttings (Chaves et al., 2004; Pádua et al., 2011). Thus, in vitro cultivation techniques support propagation with efficient multiplication protocols in cases of low germination. For the Passiflora genus, these protocols are developed by combining explant types (Antoniazzi et al., 2018; Silva et al., 2020), the growth regulators (Faria et al., 2018), and the culture environment (Vieira et al., 2014).

Thus, this paper aims to present a protocol for in vitro multiplication and regeneration of $P$. setacea plants induced to morphogenesis from the use of cytokinins 6-benzyladenine (BA) and thidiazuron (TDZ) for three types of explants, hypocotyl (HP), nodal segment (NS) and root segment (RS). 


\section{Material And Methods}

Seeds of $P$. setacea (cultivar BRS Pérola do Cerrado, crop from 2015/2016) from the Embrapa Mandioca e Fruticultura germplasm bank were used. The research was carried out in the Horticulture Sector of the Phytotechnics Laboratory of Universidade Estadual do Norte Fluminense Darcy Ribeiro (UENF).

The explants HP, NS, and RS were obtained from seedlings 35 days after in vitro germination. For the induction of morphogenesis, it was used the MSM medium (Monteiro et al., 2000), plus $30.0 \mathrm{~g} \mathrm{~L}^{-1}$ of sucrose, $0.10 \mathrm{~g} \mathrm{~L}^{-1}$ of myo-inositol, vitamins of White (Murashige and Skoog, 1962), pH of medium adjusted to $5.7 \pm 0,1$ before adding $7.0 \mathrm{~g} \mathrm{~L}^{-1}$ of agar (Vetec $\circledast$ ) and autoclaved for 20 minutes at $121^{\circ} \mathrm{C}$ and $1.1 \mathrm{~atm}$ of pressure.

The experiment was installed in a completely randomized design, in a $4 \times 4$ factorial scheme, to test for each type of explant (HP, NS, and RS) four concentrations of BA $\left(0.00 ; 2.22 ; 4.44\right.$; and $\left.8.88 \mu \mathrm{mol} \mathrm{L}^{-1}\right)$ combined with four concentrations of TDZ $\left(0.00 ; 2.27 ; 4.54\right.$ and $\left.6.81 \mu \mathrm{mol} \mathrm{L}^{-1}\right)$ with three replicates, each consisting of a Petri dish $(90 \mathrm{~mm} \times 15 \mathrm{~mm})$ with $25 \mathrm{~mL}$ of culture medium and three explants. The plates were kept in a growth room for 55 days to check the percentage of callus formation and sprouts in the explants, in addition to visual descriptive evaluation with the aid of a stereoscopic microscope (Tecnival®).

The explants that formed shoots were induced to elongate in MSM medium, supplemented with 2.88 $\mu \mathrm{mol} \mathrm{L} \mathrm{L}^{-1}$ of gibberellic acid $\left(\mathrm{GA}_{3}\right), 30.0 \mathrm{~g} \mathrm{~L}^{-1}$ of sucrose, $0.10 \mathrm{~g} \mathrm{~L}^{-1}$ of myo-inositol, White's vitamins (Murashige and Skoog, 1962), $\mathrm{pH}$ of the medium adjusted to $5.7 \pm 0.1$ before the addition of $7.0 \mathrm{~g} \mathrm{~L}^{-1}$ of agar $(\operatorname{Vetec} \AA), 40 \mathrm{~mL}$ of medium were distributed in flasks $(125 \mathrm{~mm} \times 60 \mathrm{~mm})$, then autoclaved for 20 min at $121^{\circ} \mathrm{C}$ and $1.1 \mathrm{~atm}$. The flasks were kept in a growth room and after 60 days, the shoots in the elongation phase were evaluated and followed by rooting. The explants that formed shoots were induced to elongate in MSM medium, supplemented with $4.92 \mu \mathrm{mol} \mathrm{L}^{-1}$ of gibberellic acid (GA3), $30.0 \mathrm{~g} \mathrm{~L}^{-1}$ of sucrose, $0.10 \mathrm{~g} \mathrm{~L}^{-1}$ of myo-inositol, White's vitamins (Murashige and Skoog, 1962), pH of the medium adjusted to $5.7 \pm 0.1$ before the addition of $7.0 \mathrm{~g} \mathrm{~L}^{-1}$ of agar (Vetec $\circledast$ ), $40 \mathrm{~mL}$ of medium were distributed in flasks $(125 \mathrm{~mm} \times 60 \mathrm{~mm})$, then autoclaved for $20 \mathrm{~min}$ at $121^{\circ} \mathrm{C}$ and $1.1 \mathrm{~atm}$. Afterward, they were kept in flasks with medium for 30 days in a growth room for the rooting process, and then they were taken to acclimatization. The rooted plants were transplanted into disposable cups with a substrate composed of 1:1 (Basaplant $\AA$ ) and sand, at an average temperature of $27^{\circ} \mathrm{C}$, remaining under greenhouse conditions for 60 days.

\section{Preparation of samples for anatomical characterization}

For anatomical characterization, samples of the three explants (HP, NS, and RS) were collected after 30 days in the morphogenic induction medium and fixed (Klein et al., 2004). The selected samples were washed with sodium cacodylate buffer and dehydrated in ascending alcoholic series (10\% to $90 \%$ ) and included in Historesina ${ }^{\circledR}$ Kit (Kraus; Arduin, 1997, adjusted) for the transverse sectioning at an average 
thickness of $5 \mu \mathrm{m}$ with a rotary microtome (SM 2010R, LEICA, Germany). The histological sections were stained with Toluidine Blue O (Johansen, 1940; Sass, 1941; Feder and O'Brien, 1968), mounted on permanent slides, and were visualized under a light microscope (Axioplan, ZEISS, USA) with a digital camera (Moticam Pro 282A, MOTIC®, Asia) for capturing images.

To determine whether the data would meet the assumptions of analysis of variance (ANOVA), they were subjected to preliminary analyses to determine the normality and homogeneity of variances among treatments, for each factor, based on the Lilliefors (1967) and Bartlett, Bobko, and Mosier (1978) tests. Subsequently, the data were subjected to analysis of variance, and the means were compared according to the Tukey's test at 5\% probability, utilizing the software SISVAR® (Statistical Analysis System, 5.6 version) (Ferreira, 2011).

\section{Results And Discussion}

In callogenesis, it was observed that the explants from the aerial part of the plant (HP and NS), when submitted to the medium without plant growth regulator, did not presently callus formation. On the other hand, there was callus formation in RS in the absence of plant growth regulator (PGR). For explants derived from HP and NS, any isolated concentration of TDZ and BA induces callus formation. The high concentrations of cytokinins BA and TDZ combined favor the proliferation of calluses in HP and NS, however, they are harmful in the formation of calluses derived from RS (Table 1). According to Huetteman and Preece (1993), at low concentrations ( $<1 \mu \mathrm{M})$ TDZ can induce greater proliferation of shoots than many other cytokinins, but it can inhibit their elongation. At concentrations above $1 \mu \mathrm{M}$, however, TDZ can stimulate callus formation, pursuant to results presented in this paper. 
Table 1

Percentage of callus formation in the explants: hypocotyl (HP) (A), nodal segment (NS) (B) and root segment (RS) (C) of P. setacea submitted to different concentrations of BA and TDZ.

\section{(A) Hypocotyol}

TDZ

( $\left.\mu \mathrm{mol} \mathrm{L}^{-1}\right)$

0.00

2.27

4.54

6.81

Mean

MSD:

(B) Nodal Segment

\begin{tabular}{l}
0.00 \\
2.27 \\
4.54 \\
6.81 \\
Mean \\
MSD: \\
(C) Root Segment \\
\hline
\end{tabular}

0.00

2.27

4.54

6.81

Mean

MSD:

Means followed by equal uppercase letters in the line and lowercase in the column do not differ among them $(p \leq 0.05)$ according to the Tukey-test.
Mean

$\begin{array}{ll}4.44 & 8.88\end{array}$

$77.66 \mathrm{aA}$

83.33 aA

$63.66 b$

$\begin{array}{lll}89.00 \mathrm{aA} & 100.00 \mathrm{aA} \quad 97.33 \mathrm{a}\end{array}$

$77.66 \mathrm{aA} \quad 100.00 \mathrm{aA}$

$89.00 \mathrm{aA}$

$0.00 \mathrm{bB}$

$63.66 \mathrm{~b}$

$100.00 \mathrm{aA}$

69.33 B

$100.00 \mathrm{aA}$

$100.00 \mathrm{aA}$

$22.33 \mathrm{bB}$

$80.66 \mathrm{ab}$

$100.00 \mathrm{~A}$

$89.00 \mathrm{~A}$

$48.33 \mathrm{C}$

76.67
0.5802

$\begin{array}{lllll}0.00 \mathrm{bB} & 89.00 \mathrm{aA} & 77.66 \mathrm{aA} & 100.00 \mathrm{aA} & 66.66 \mathrm{~b} \\ 100.00 \mathrm{aA} & 100.00 \mathrm{aA} & 100.00 \mathrm{aA} & 100.00 \mathrm{aA} & 100.00 \mathrm{a} \\ 100.00 \mathrm{aA} & 100.00 \mathrm{aA} & 100.00 \mathrm{aA} & 0.00 \mathrm{bB} & 75.00 \mathrm{~b} \\ 100.00 \mathrm{aA} & 100.00 \mathrm{aA} & 100.00 \mathrm{aA} & 100.00 \mathrm{aA} & 100.00 \mathrm{a} \\ 75.00 \mathrm{~B} & 97.33 \mathrm{~A} & 94.33 \mathrm{~A} & 75.00 \mathrm{~B} & 85.33\end{array}$

0.3571
$22.33 \mathrm{aB}$

$66.66 \mathrm{aA}$

$66.66 \mathrm{aA}$

$66.66 \mathrm{aA}$

$55.67 \mathrm{~B}$

0.7318

The use of explants combined with different concentrations of BA and TDZ contributed to de novo organogenesis (Table 2). RS formed calluses and shoots even in the absence of PGR (Table 2C). This 
response is reported using this same type of explant in other Passiflora species (Lombardi et al., 2007). This is due to the endogenous balance of this type of tissue, as cytokinins are synthesized in the roots (Aloni et al., 2006). Thus, by excising the root, cytokinin activity increases (Van Staden and Smith, 1978), inducing the formation of calluses and shoots on the roots even without the addition of the PGR to the medium. On the other hand, explants extracted from the aerial part (HP and SN) when submitted to the absence of PGR did not show significant de novo organogenesis. In this study, direct and indirect organogenesis was observed. The direct was detected in NS and RS (Fig. 1a, b; 2 c, e, f) with a vascular system directly connected to the vascular tissue of the explant. This pattern was not observed in HP derivatives, for the conditions mentioned. 
Table 2

Shoot formation percentage in explants from hypocotyl (HP) (A), nodal segment (NS) (B) and root segment (RS) (C) of P. setacea submitted to different concentrations of BA and TDZ.

\section{(A) Hypocotyl}

$\operatorname{TDZ}(\mu \mathrm{mol} \mathrm{L}-1)$

BA $\left(\mu \mathrm{mol} \mathrm{L}{ }^{-1}\right)$

Mean

\begin{tabular}{llllll} 
& $\mathbf{0 . 0 0}$ & $\mathbf{2 . 2 2}$ & $\mathbf{4 . 4 4}$ & $\mathbf{8 . 8 8}$ & \\
$\mathbf{0 . 0 0}$ & $0.00 \mathrm{bB}$ & $100.00 \mathrm{aA}$ & $77.66 \mathrm{aA}$ & $83.33 \mathrm{aA}$ & $63.66 \mathrm{~b}$ \\
$\mathbf{2 . 2 7}$ & $100.00 \mathrm{aA}$ & $100.00 \mathrm{aA}$ & $89.00 \mathrm{aA}$ & $100.00 \mathrm{aA}$ & $97.33 \mathrm{a}$ \\
$\mathbf{4 . 5 4}$ & $77.66 \mathrm{aA}$ & $100.00 \mathrm{aA}$ & $55.67 \mathrm{aA}$ & $0.00 \mathrm{bB}$ & $54.67 \mathrm{~b}$ \\
$\mathbf{6 . 8 1}$ & $77.66 \mathrm{aA}$ & $100.00 \mathrm{aA}$ & $77.66 \mathrm{aA}$ & $22.33 \mathrm{bB}$ & $69.33 \mathrm{~b}$ \\
Mean & $64.00 \mathrm{BC}$ & $100.00 \mathrm{~A}$ & $75.00 \mathrm{AB}$ & $48.33 \mathrm{C}$ & 71.67 \\
\hline MSD: & 0.7522 & & & &
\end{tabular}

(B) Nodal Segment

$\operatorname{TDZ}\left(\mu \mathrm{mol} \mathrm{L}{ }^{-1}\right) \quad$ BA $\left(\mu \mathrm{mol} \mathrm{L}^{-1}\right)$

Mean

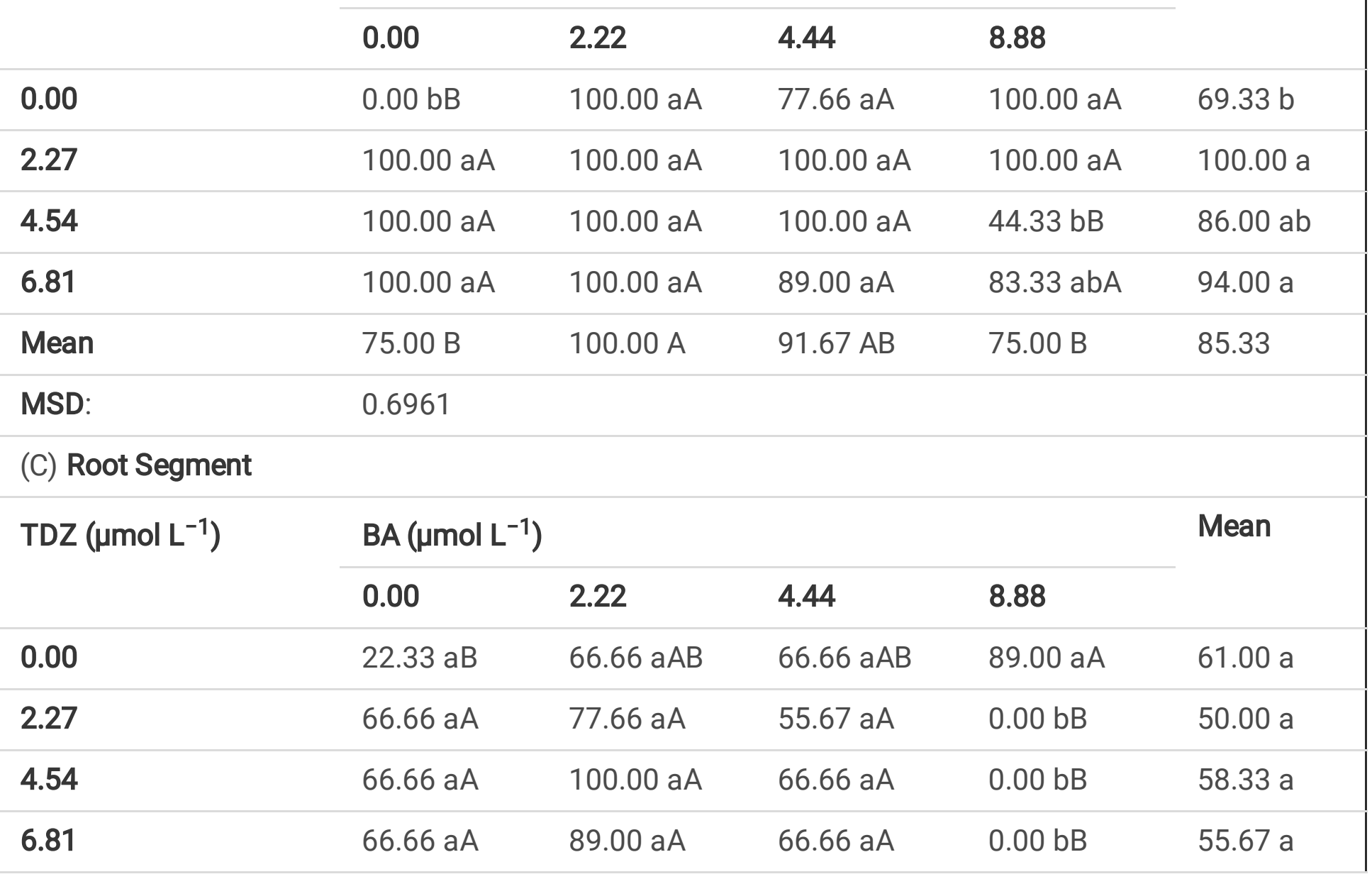

Means followed by equal uppercase letters in the line and lowercase in the column do not differ among them $(p<0.05)$ according to the Tukey test. 


\section{(A) Hypocotyl}

\begin{tabular}{llllll} 
Mean & $55.67 \mathrm{~B}$ & $83.33 \mathrm{~A}$ & $64.00 \mathrm{AB}$ & $22.33 \mathrm{C}$ & 56.33 \\
\hline MSD: & 0.8143 & & & &
\end{tabular}

Means followed by equal uppercase letters in the line and lowercase in the column do not differ among them $(p<0.05)$ according to the Tukey test.

A diversity of explants can be explored to establish an efficient in vitro regeneration protocol in species of the genus Passiflora (Garcia et al., 2011; Antoniazzi et al. 2018; Faria et al., 2018). All three types of explants were able to regenerate at least one complete plant from an induction medium supplemented with BA. The explants derived from NS are the most responsive to regeneration.

The treatment with the highest number of shoots had the highest number of regenerated plants. Vieira et al. (2014) state that it is expected that explants more responsive in the morphogenic stage are those presenting a greater number of regenerated plants. In the following steps of elongation and rooting it was found that the treatments, which in the morphogenic step presented TDZ in the medium, were not successful for plant regeneration. TDZ can have a cumulative effect over cycles by inhibiting the elongation and rooting of shoots (Huetteman and Preece, 1993).

The anatomical analyses revealed that the morphogenetic responses observed in HP, NS, and RS began with the intense asymmetric divisions of the explant originated cell clusters with cytological characteristics with the new meristemoids. These cells are small, isodiametric, with reduced volume, dense cytoplasm, and evident nucleus compared to adjacent cells that are already more developed and vacuolated. So, rise meristematic regions proliferating precursor cells with stem cell-like properties with an intense callus formation along with the cutting areas of leaf-derived and HP explants that later differentiate into shoots. Organogenesis was observed both indirectly (Fig. 2a, b) and directly (Fig. 2c-f) as observed in the RS (Fig. 2e, f), in which the vascular system tends to connect to the vascular tissue of the explant, consistent with the pattern of organogenic regeneration. Consequently, organogenic structures appear, giving origin to leaf primordial, stem gems, and other tissue in NS (Fig. 2c) and root apex in RS (Fig. 2f). These structures were observed over the callus (Fig. 2).

All types of explants had elongated shoots derived from at least four different concentrations of BA $x$ TDZ in the morphogenesis phase (Fig. 3a). The largest number of rooted plants was obtained from shoots derived from NS induced in medium supplemented with $2.22 \mu \mathrm{mol} \mathrm{L}^{-1}$ BA without TDZ (Fig. 3b). For shoots derived from HP and SR, the rooting of 1 and 2 shoots, respectively, was observed (Fig. 3b). The rooted plants were acclimatized for 60 days in a greenhouse, being obtained 15 acclimatized and well-developed plants. At least one plant was fully regenerated and acclimatized for the three types of explants (HP, NS, and RS), which confirms the development of an efficient protocol for in vitro morphogenesis in P. setacea (Fig. 4). 


\section{Conclusion}

In this study, it was possible to obtain the regeneration of $P$. setacea plants after in vitro morphogenesis using HP and NS in medium with $2.22 \mu \mathrm{mol} \mathrm{L}^{-1} \mathrm{BA}$ and using RS in medium with $8.88 \mu \mathrm{mol} \mathrm{L}^{-1} \mathrm{BA}$. Therefore, we recommend using explants derived from NS and MSM medium supplemented with 2.22 $\mu \mathrm{mol} \mathrm{\textrm {L } ^ { - 1 }}$ of BA for the in vitro morphogenesis of Passiflora setacea.

\section{Declarations}

\section{CONTRIBUTION OF AUTHORS}

LSA conducted the experiments and wrote the manuscript. VSC supervised the research. ALG contributed to conducting and evaluating the experiments. JGSS contributed to statistical analysis and graphing. GC conducted the anatomical analyses. RW contributed to the statistical analyses. MC inspected the anatomical analyses. Finally, all authors reviewed the manuscript.

\section{FUNDING}

The authors would like to thank the Universidade Estadual do Norte Fluminense Darcy Ribeiro for the structure of laboratories used. This study was also financed in part by the Coordenação de Aperfeiçoamento de Pessoal de Nível Superior - Brasil (CAPES) finance code 001.

\section{CONFLICT OF INTEREST}

The authors declare no conflict of interest.

\section{ETHICAL APPROVAL}

This article does not contain any studies with participating humans or animals performed by any of the authors.

\section{References}

1. Aloni R, Aloni $\mathrm{E}$, Langhans $\mathrm{M}, \mathrm{Ull}$ rich $\mathrm{Cl}$ (2006) Role of cytokinin and auxin in shaping root architecture: regulating vascular differentiation, lateral root initiation, root apical dominance and root gravitropism. Ann Bot 97(5):883-893. https://doi.org/10.1093/aob/mcl027

2. Antoniazzi CA, Faria RB, Carvalho PP, Mikovski Al, Carvalho IF, Matos EM, Reis AC, Viccini LF, Paim Pinto DL, Rocha DI, Otoni WC, Silva ML (2018) In vitro regeneration of triploid plants from mature endosperm culture of commercial passionfruit (Passiflora edulis Sims). Sci Hortic 238:408-415. https://doi:10.1016/j.scienta.2018.05.001.

3. Bartlett, C. J., Bobko, P., Mosier, S. B., Hannan, R. (1978). Testing for fairness with a moderated multiple regression strategy: An alternative to differential analysis. Personnel Psychology, 31, 233241. https://doi.org/10.1111/j.1744-6570.1978.tb00442.x 
4. Carvalho BM, Viana AP, Dos Santos PHD, Generoso AL, Corrêa CCG, Silveira V, Eiras M, Santos E A (2019) Proteome of resistant and susceptible Passiflora species in the interaction with cowpea aphid-borne mosaic virus reveals distinct responses to pathogenesis. Euphytica 215: 167. https://doi.org/10.1007/s10681-019-2491-5

5. Chaves RC, Junqueira NTV, Manica I, Peixoto JR, Pereira AV, Fialho JF (2004) Enxertia de maracujazeiro-azedo em estacas herbáceas enraizadas de espécies de passifloras nativas. Rev Bras de Frutic 26(1):120-123. http://dx.doi.org/10.1590/S0100-29452004000100033

6. Faria RB, Carvalho IF, Rossi AAB, Matos EM, Rocha DI, Pinto DLP, Otoni WC, Silva ML (2018) High responsiveness in de novo shoot organogenesis induction of Passiflora cristalina (Passifloraceae), a wild Amazonian passion fruit species. In Vitro Cell Dev Biol Plant 54: 166-174. https://doi.org/10.1007/s11627-017-9881-y

7. Feder N, O'Brien TP (1968) Plant microtechnique: some principles and new methods. Am J Bot 55(1): 123-142. https://doi: $10.2307 / 2440500$

8. Ferreira DF (2011) Sisvar: A computer statistical analysis system. Ciênc Agrotec 35(6):1039-1042. https://doi.org/10.1590/S1413-70542011000600001.

9. Fuhrmann E, Junqueira NTV, Blum LEB, Braga MW, Bellon G, Junqueira K P (2014) Reaction of interspecific hybrids of Passiflora spp. to Xanthomonas axonopodis pv. passiflorae. Ciênc Rural 44(8):1404-1410. https://doi.org/10.1590/0103-8478cr20121092.

10. Gamborg OL, Miller RA, Ojima K (1968) Nutrient requirements of suspension cultures of soybean root cells. Exp Cell Res 50(1):151-158. https://doi.org/10.1016/0014-4827(68)90403-5

11. Garcia, R., Pacheco, G., Falcão, E., Borges, G., Mansur, E. (2011) Influence of type of explant, plant growth regulators, salt composition of basal medium, and light on callogenesis and regeneration in Passiflora suberosa L.(Passifloraceae). Plant Cell Tiss Org Cult 106(1):47-54. https://doi.org/10.1007/s11240-010-9892-4

12. Huetteman, C.A. and Preece, J.E. (1993) Thidiazuron: A potent cytokinin for woody plant tissue culture. Plant Cell Tiss Org Cult 33:105-119. https://doi:10.1007/BF01983223

13. Johansen DA (1940) Plant microtechnique. McGraw Hill Book.

14. Klein DE, Gomes VM, Silva-Neto SJ, Cunha M. (2004) The structure of colleters in several species of Simira (Rubiaceae). Ann Bot 94:733-740. https://doi.org/10. 1093/aob/mch198.

15. Kraus, J.E.; Arduin, M. (1997) Manual Básico de métodos em morfologia vegetal. Seropédica -RJ: EDUR - Editora Universidade Rural. 198 p.

16. Lilliefors, H.W. (1967) On the Kolmogorov-Smirnov test for normality with mean and variance unknown. J Am Stat Assoc, 62(318):399-402. https://doi: 10.1080/01621459.1967.10482916

17. Lombardi SP, Passos IRS, Nogueira MCS, Appezzato-da-Gloria B. (2007) In vitro shoot regeneration from roots and leaf discs of Passiflora cincinnata Mast. Braz Arch Biol and Technol 50(2):239-247. https://doi.org/10.1590/S1516-89132007000200009

18. Monteiro ACBA, Higashi EN, Gonçalves AN, Rodriguez APM (2000a) A novel approach for the definition of the inorganic medium components for micropropagation of yellow passionfruit 
(Passiflora edulis Sims. f. flavicarpa Deg.). In Vitro Cell Dev Biol Plant 36:527-531. https://doi.org/10.1007/s11627-000-0094-3.

19. Murashige T, Skoog F (1962) A revised medium for rapid growth and bioassays with tobacco tissue cultures. Physiol Plant 15(3):473-497. https:// doi:10.1111/j.1399-3054.1962.tb08052.x

20. Pádua JG, Schwingel LC, Mudim RC, Salomão AN, Roverijosé SCB (2011). Germinação de sementes de Passiflora setacea e dormência induzida pelo armazenamento. Rev Bras Sem 33(1):080-085. https://doi.org/10.1590/S0101-31222011000100009.

21. Sacoman N N, Viana A P, Carvalho, V S, Santos EA, Rodrigues R (2018) Resistência ao Cowpea aphid-borne mosaic virus em genótipos de Passiflora setacea germinadas in vitro. Rev Bras Frutic 40:607. https://doi.org/10.1590/0100-29452017607

22. Santos EA, Viana AP, Walter FHB, Freitas JCO, Ramos HCC, Boechat MSB (2019) First report of a genetic map and evidence of QTL for resistance to CABMV in a segregating population of Passiflora. Eur J Plant Pathol 155:903-915. https://doi.org/10.1007/s10658-019-01822-y

23. Sass JE (1941). Elements of Botanical Microtechnique Nature 148:241. https://doi.org/10.1038/148241b0

24. Silva, N.T., Silva, L.A.S., Reis, A.C., Machado, M., Matos, E.M., Viccini, L.F., Otoni, W.C., Carvalho, I.F., Rocha, D.I., Silva, M.L. (2020). Endosperm culture: a facile and efficient biotechnological tool to generate passion fruit (Passiflora cincinnata Mast.) triploid plants. Plant Cell Tiss Organ Cult 142:613-624. https://doi.org/10.1007/s11240-020-01887-2

25. Van Staden J, Smith AR (1978) The synthesis of cytokinins in excised roots of maize and tomato under aseptic conditions. Ann Bot 42(179):751-753.

https://doi.org/10.1093/oxfordjournals.aob.a085509

26. Viana AP, Silva FHLE, Gonçalves GM, Silva MGM, Ferreira RT, Pereira TNS, Pereira MG, Amaral Júnior AT, Carvalho GF (2016) UENF Rio Dourado: a new passion fruit cultivar with high yield potential. Crop Breed Appl Biotechnol 16:250-253. https://doi.org/10.1590/1984-70332016v16n3c38

27. Vieira LM, Rocha DI, Taquetti MF, Silva LC, Campos JMS, Viccini LF, Otoni WC (2014) In vitro plant regeneration of Passiflora setacea D.C. (Passifloraceae): the influence of explant type, growth regulators, and incubation conditions. In Vitro Cell Dev Biol Plant 50:738-745. https://doi.org/10.1007/s11627-014-9650-0

\section{Figures}



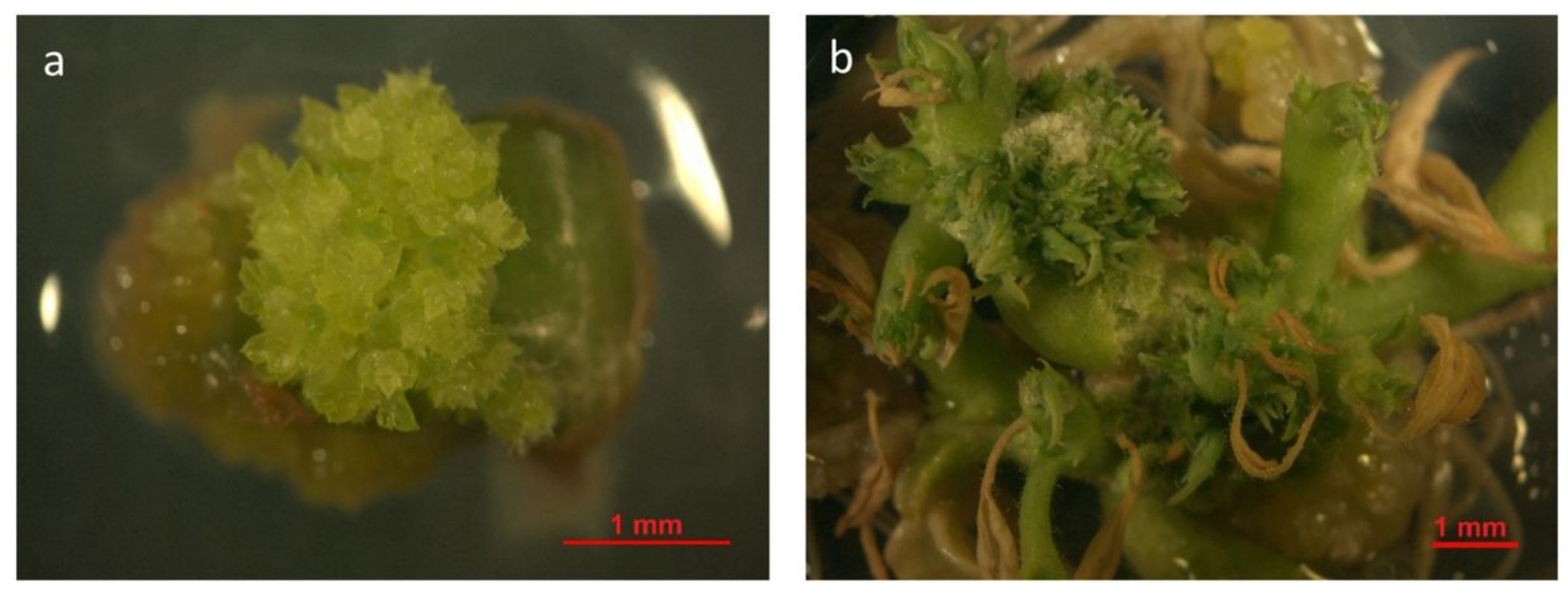

Figure 1

Direct organogenesis in NS (a) and RS (b), at the respective concentrations of $8.88 \mu \mathrm{mol} \mathrm{L}^{-1}$ of BA with $4.54 \mu \mathrm{mol} \mathrm{L}-1$ of TDZ and $4.44 \mu \mathrm{mol} \mathrm{L}^{-1}$ of BA and $0.00 \mu \mathrm{mol} \mathrm{L}^{-1}$ of TDZ, after 30 days of in vitro morphogenesis induction $(\mathrm{bar}=1 \mathrm{~mm}$ ). 

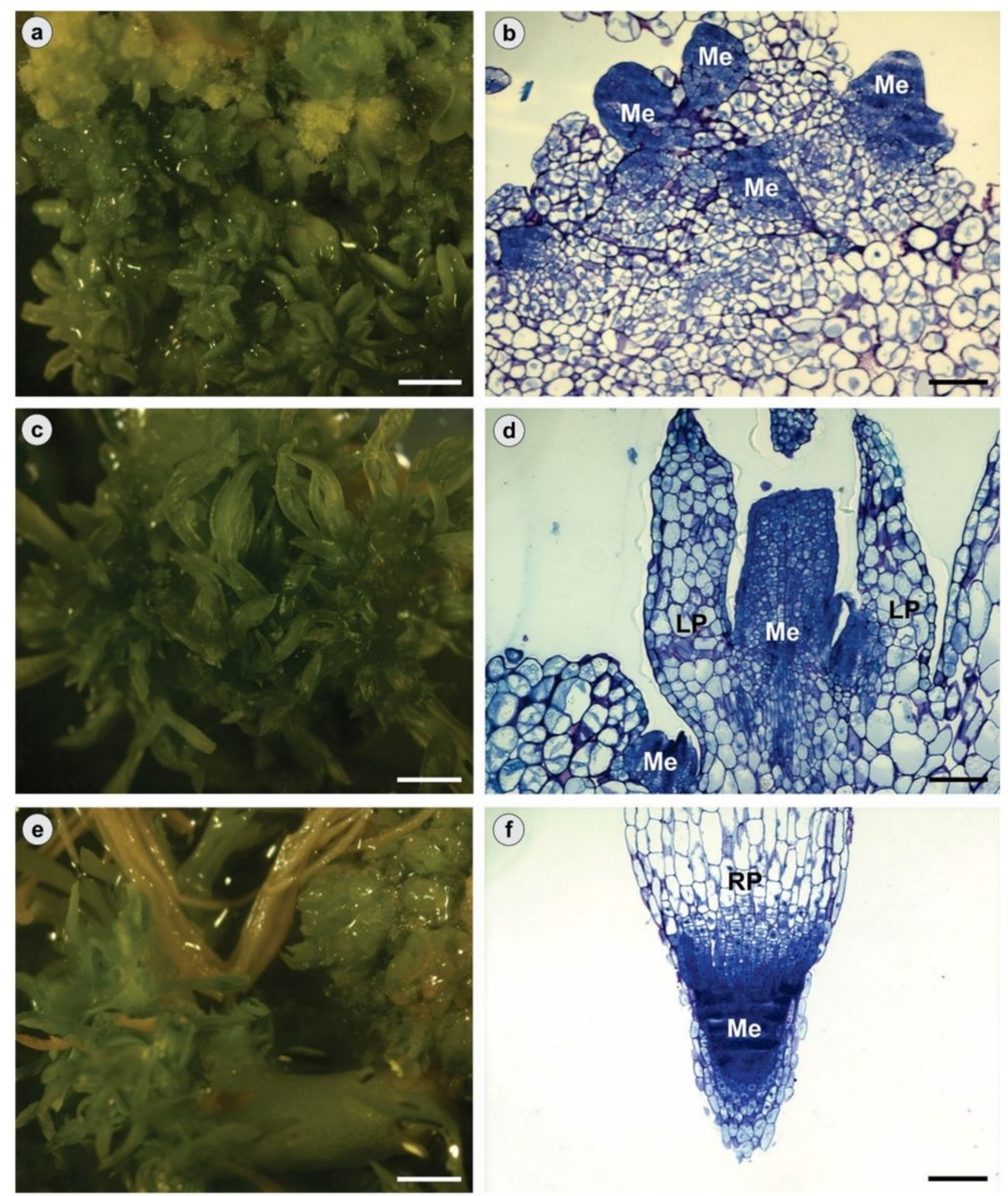

\section{Figure 2}

In vitro development of $P$. setacea after 30 days in induction medium of the morphogenic stage. $(\mathbf{a}, \mathbf{c}, \mathbf{e})$ : Stereoscopy microscope. (b, d, f): Light microscopy. (a-b): HP submitted to the induction medium with $2.22 \mu \mathrm{mol} \mathrm{L}{ }^{-1}$ BA e $4,54 \mu \mathrm{mol} \mathrm{L}^{-1} \mathrm{TDZ}$. (c-d): NS submitted to the induction medium with $2.22 \mu \mathrm{mol} \mathrm{L}^{-1} \mathrm{BA}$ e $0.00 \mu \mathrm{mol} \mathrm{L} \mathrm{L}^{-1}$ TDZ. (e-f): RS submitted to the induction medium with $8.88 \mu \mathrm{mol} \mathrm{L}^{-1} \mathrm{BA}$ e $0.00 \mu \mathrm{mol} \mathrm{L}^{-1}$ 
TDZ. It is possible to observe the presence of meristemoids $(\mathrm{Me})$ in the three types of explants $(\mathbf{b}, \mathbf{d}, \mathbf{f})$, leaf primordia (LP) (d) and root primordia (RP) (f). Bars: a, c, e: $1 \mathrm{~mm}$. b, d, f: $100 \mu \mathrm{m}$.
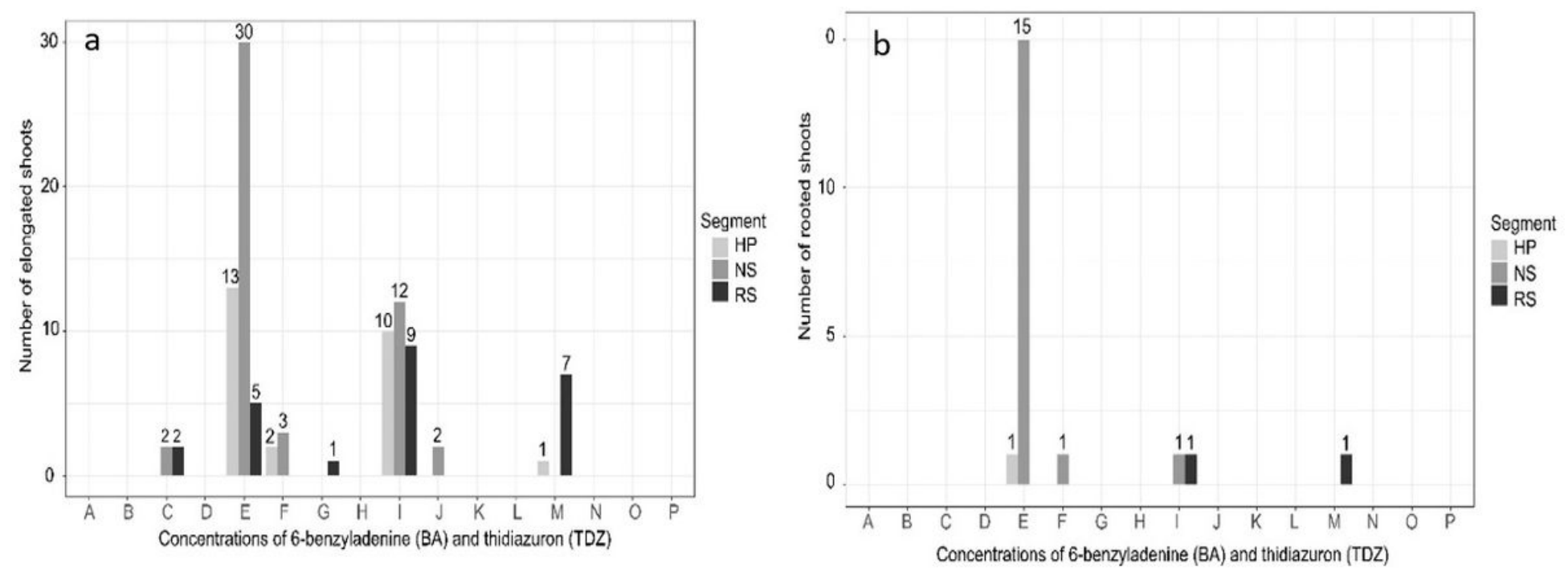

Figure 3

Number of elongated (a) and rooted (b) shoots derived from HP, NS and RS of $P$. setacea cultivated in different concentrations of $\mathrm{BA}$ and TDZ in $\mu \mathrm{mol} \mathrm{L}^{-1}$, respectively. A - $0.00+0.00 ; \mathrm{B}-0.00+2.27 ; \mathrm{C}-0.00+$ 4.54; D - $0.00+6.81 ; E-2.22+0.00 ; \mathrm{F}-2.22+2.27 ; \mathrm{G}-2.22+4.54 ; \mathrm{H}-2.22+6.81 ; \mathrm{I}-4.44+0.00 ; \mathrm{J}-4.44$ $+2.27 ; \mathrm{K}-4.44+4.54 ; \mathrm{L}-4.44+6.81 ; \mathrm{M}-8.88+0.00 ; \mathrm{N}-8.88+2.27 ; 0-8.88+4.54 ; \mathrm{P}-8.88+6.81$.

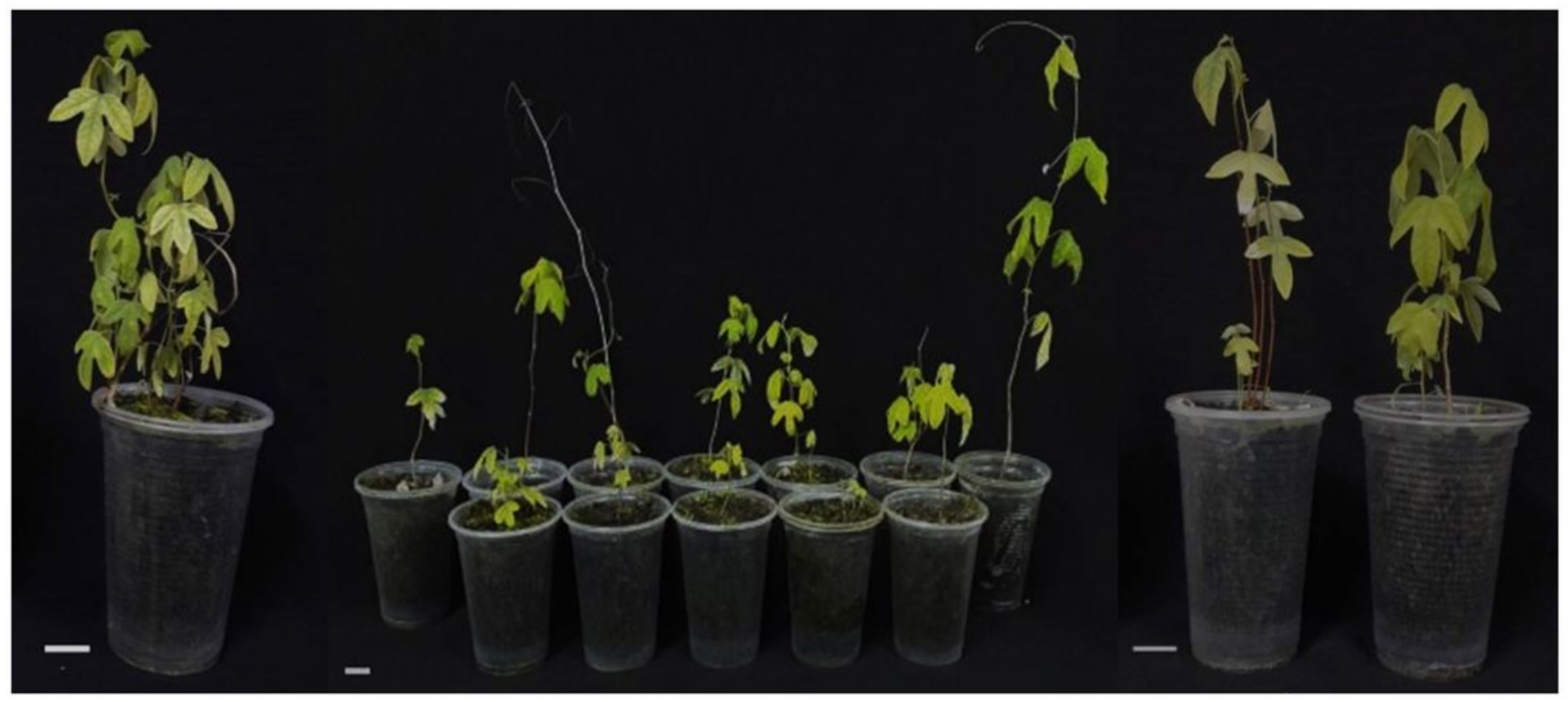

Figure 4 
Plants acclimatized in a greenhouse for 60 days. One plant from HP at a concentration of $2.22 \mu \mathrm{mol} \mathrm{L} \mathrm{L}^{-1}$ BA $\times 0.00 \mu \mathrm{mol} \mathrm{L}^{-1} \mathrm{TDZ}(\mathrm{a}), 12$ plants from NS at concentrations of $2.22 \mu \mathrm{mol} \mathrm{L} \mathrm{L}^{-1} \mathrm{BA} \times 0.00 \mu \mathrm{mol} \mathrm{L}^{-1} \mathrm{TDZ}$ (b), two plants from RS, at concentrations of $8.88 \mu \mathrm{mol} \mathrm{L}^{-1} \mathrm{BA} \times 0.00 \mu \mathrm{mol} \mathrm{L}^{-1} \mathrm{TDZ}$ and $4.44 \mu \mathrm{mol} \mathrm{L}{ }^{-1} \mathrm{BA}$ x $0.00 \mu \mathrm{mol} \mathrm{L}^{-1} \mathrm{TDZ}$, respectively, (c) (bar $\left.=20 \mathrm{~cm}\right)$. 